\title{
MODELLING THE MELTING TEMPERATURE OF A LIPID-BASED CRITICAL TEMPERATURE INDICATOR: A COMPARISION BETWEEN SIMPLEX-LATTICE AND SIMPLEX-CENTROID DESIGNS
}

\author{
KARINE CRISTINE KAUFMANN* \\ ODINEI HESS GONÇALVES* \\ EVANDRO BONA* \\ FERNANDA VITÓRIA LEIMANN*
}

\begin{abstract}
Critical temperature indicators (CTI) find applications in food industry in cases when defrost may not occur or a specific temperature may not be reached, , indicating changes through visual changes, such as melting, color changes, etc. Lipid mixtures are promising candidates to formulate $\mathrm{CTI}$ since the final melting point of the mixture may be manipulated by the proportion of each lipid. In this work a lipid mixture consisting of stearic acid, lard and peanut oil was used to develop a CTI mixture. Simplex-lattice and Simplex-centroid experimental designs were compared to modelling the melting temperature of the lipid mixture. Addition of axial points to the experimental design improved predictive ability of the models while the inclusion of inverse terms was necessary to improve models accuracy. Simplex-lattice design presented an improved ability to predict the melting point of binary mixtures, while the simplex-centroid design resulted in an improved model for predicting melting point of the ternary mixtures.
\end{abstract}

KEY-WORDS: SIMPLEX-LATTICE; SIMPLEX-CENTROID; FATTY ACIDS; MELTING POINT.

${ }^{1}$ Federal University of Technology - Paraná (UTFPR), Food Department (DALIM), Caixa Postal 271, BR 369, km 0.5, CEP 87301-006, Campo Mourão, PR, Brazil.

${ }^{2}$ Federal University of Technology - Paraná (UTFPR), Post-Graduation Program of Food Technology (PPGTA), Caixa Postal 271, BR 369, km 0.5, CEP 87301-006, Campo Mourão, PR, Brazil. e-mail: fernandaleimann@ utfpr.edu.br 


\section{INTRODUCTION}

Temperature is one of the most important factors affecting food quality and safety. While food package can easily control factors such as atmospheric composition and relative humidity, food temperature depends on storage and distribution conditions (SHIMONI; ANDERSON; LABUZA, 2001). If temperature is not satisfactorily controlled during the cold chain, sensory properties of foodstuff may be compromised. In many cases some degree of risk to consumers are also involved (PEREIRA et al., 2010).

Sensors or indicators can be applied to food packages to control or supervise storage and transportation conditions of frozen or chilled products. Time-temperature indicators available to the food industry may be classified in critical temperature indicators, partial history indicators and complete history indicators (BIJI et al., 2015; PAVELKOVÁ, 2013). Irreversible temperature changes are usually denoted by visual response of mechanical deformation, color change by mechanical, chemical, enzymatic or microbiological mechanisms (Pavelková, 2013; Smolander and others, 2004; Wang and others., 2015; Zabala and others, 2015). According to Taoukis (2001) critical temperature indicators are simpler, cheaper versions of such sensors which show if foodstuff was exposed to a certain temperature that may be avoided. Melting or solidification can be used as an indicator of a limit temperature exposition (PAVELKOVÁ, 2013), however the downside is that no historic registration showing how temperature oscillated during time is recorded.

To develop temperature indicators, with the melting temperature as driving mechanism, composed by natural substances is a challenge because of their complex composition which leads to melting in a range of temperatures instead of presenting a true melting point. This is the case of natural lipids such as oils and fats that are composed by complex triglycerides mixtures that pass through a gradual softening before turning into a complete liquid mixture (FASINA et al., 2008; KOUAKOU; LE MAPIHAN; PAULY, 2013; SENGAR; SHARMA; KUMAR, 2015). Nevertheless, lipid mixtures are candidates to formulate critical temperature indicators because a wide range of melting temperatures may be achieved by mixing lipids of different melting points such as solid fats and oils. The capillary tube method (CC1-25) is an AOCS (American Oil Chemists' Society) official method (AOCS, 1989) for melting point determination, considered s cheap and robust (SETIOWATY; MAN, 2002) and has been applied to different lipids melting point determinations such as cocoa butter (LIU; CHANG; LIU, 2007), palm oil blends (SETIOWATY; MAN, 2002), lard modified by Lipozyme RM IM-catalyzed acidolysis (YANG et al., 2003), interestified and hydrogenated soybean oil (PACHECO et al., 2013).

The addition of small amounts of liquid oils to solid lipids may lead to the reduction of the final melting temperature (MÜLLER; RADTKE; WISSING, 2002). However, the exact composition that leads to the desired critical temperature indicator is of key importance. Moreover, the ability to obtain different critical temperature indicators by simply changing the proportion between components is desired for an industrial point of view. Mixture experimental designs are mathematical tools with the ability to model mixture behavior in a wide range of composition with increasing application in food industry and research (BRITO et al., 2014; DOGAN et al., 2014; NIKZADE; TEHRANI; SAADATMANDTARZJAN, 2012). Good candidates to be mixed and compose lipid based critical temperature indicators are peanut oil, lard and stearic acid that present different melting temperatures, ranging from -2.4 to $11.5^{\circ} \mathrm{C}$ for peanut oil (MYAT et al., 2009), $42.1^{\circ} \mathrm{C}$ for lard (SILVA; GIOIELLI, 2006) and $69^{\circ} \mathrm{C}$ for stearic acid (LIMPISOPHON; TANAKA; OSAKO, 2010).

In this work, mixture experimental designs known as simplex-lattice and simplex-centroid were used to model the melting temperature, determined by the capillary tube method (CC1-25), of lipid mixtures composed by stearic acid, lard and peanut oil. Key aspects of the design setup were evaluated such as the addition of axial experimental points and inverse terms in the regression models.

\section{MATERIALS AND METHODS}

Peanut beans and lard were acquired at the local market of Campo Mourão, Paraná, Brazil. Stearic acid (95\%) was acquired from Sigma Aldrich. Petroleum ether (99\%, Vetec) was used in the extraction of peanut oil. 


\subsection{PEANUT OIL EXTRACTION}

Initially, peanut beans were crushed and then added $(50 \mathrm{~g})$ to petroleum ether $(150 \mathrm{~g})$. Extraction was carried out for 24 hours at $25^{\circ} \mathrm{C}$ under gentle stirring. After that, the dispersion was filtered and the solvent was evaporated under vacuum. Peanut oil was frozen $\left(-18^{\circ} \mathrm{C}\right)$ until use.

\subsection{MIXTURE EXPERIMENTAL DESIGN}

Four types of simplex design were evaluated to model the melting point of the ternary lipid mixtures: (CORNELL, 2011). The simplex-centroid design (Figure 1a) presents seven experimental points, however it is only possible to build a special cubic model (SC) (Equation 1).

$\hat{y}=\beta_{1} x_{1}+\beta_{2} x_{2}+\beta_{3} x_{3}+\beta_{12} x_{1} x_{2}+\beta_{13} x_{1} x_{3}+\beta_{23} x_{2} x_{3}+\beta_{123} x_{1} x_{2} x_{3}$

In Equation (1), is the mixture melting temperature predicted by the model, represents the proportion from the component in the mixture, is the main coefficient from the component, is the quadratic coefficient from the binary interaction and is the cubic coefficient from the ternary interaction (NETO; BRUNS; SCARMINO, 2010).

The $\{3,3\}$ simplex-lattice design presents ten experimental points (Figure 1c) and allows the achievement of a full cubic model (FC) (Equation 2).

$$
\begin{aligned}
\hat{y}=\beta_{1} x_{1}+\beta_{2} x_{2}+\beta_{3} x_{3}+\beta_{12} x_{1} x_{2}+\beta_{13} x_{1} x_{3}+\beta_{23} x_{2} x_{3} \\
+\delta_{12} x_{1} x_{2}\left(x_{1}-x_{2}\right)+\delta_{13} x_{1} x_{3}\left(x_{1}-x_{3}\right)+\delta_{23} x_{2} x_{3}\left(x_{2}-x_{3}\right) \\
+\beta_{123} x_{1} x_{2} x_{3}
\end{aligned}
$$

In Equation (2), in addition to the previously discussed terms that are present in Equation (1), represents the cubic coefficient related to the binary interaction which may be useful for studying changes in the shape of the response surface for binary blends of the components (CORNELL, 2011).

Simplex designs are criticized by their small number of internal points in the experimental region. An alternative may be the inclusion of axial points (Figures $1 \mathrm{~b}$ and $1 \mathrm{~d}$ ) to increase the reliability of the obtained models (MONTGOMERY, 2005). Furthermore, for simplex-centroid design, the inclusion of internal points allows the construction of a special quartic model (SQ, Equation 3) (CORNELL, 1986).

$$
\begin{gathered}
\hat{y}=\beta_{1} x_{1}+\beta_{2} x_{2}+\beta_{3} x_{3}+\beta_{12} x_{1} x_{2}+\beta_{13} x_{1} x_{3}+\beta_{23} x_{2} x_{3}+\gamma_{1123} x_{1}^{2} x_{2} x_{3}+\gamma_{1223} x_{1} x_{2}^{2} x_{3} \\
+\gamma_{1233} x_{1} x_{2} x_{3}^{2}
\end{gathered}
$$

In addition to the models presented at Equations (1), (2) and (3), the quadratic model, Equation (4), was tested for all experimental designs.

$$
\hat{y}=\beta_{1} x_{1}+\beta_{2} x_{2}+\beta_{3} x_{3}+\beta_{12} x_{1} x_{2}+\beta_{13} x_{1} x_{3}+\beta_{23} x_{2} x_{3}
$$

\subsection{MULTIVARIATE REGRESSION ANALYSIS}

The multivariate regression and the analysis of the overall goodness of fit for each experimental design and model were carried out with the software MATLAB R2008b. The designs, experimental melting points and, the regression models are described at Table 1. All experiments were carried out in duplicate in a completely randomized order. All designs were composed by three experiments with each of the pure components and one experiment with the ternary mixture or centroid (Table 1 , experiments 1 to 4). Furthermore, for simplex-centroid design the binary mixtures were also considered (experiments 11 to 13). On the other hand, to simplex-lattice design the binary mixtures are those marked with experimental runs from 5 to 10 . Both to simplex-centroid with axial points and to simplexlattice with axial points the experimental runs from 14 to 16 were added. The binary mixtures that were not applied to model construction were employed to evaluated prediction error (Equation 5). Thus, to evaluate the prediction error to simplex-centroid design the experimental runs from 5 to 10 were used (Table 1) and to simplex-lattice with axial points design the experiments from 11 to 13. 


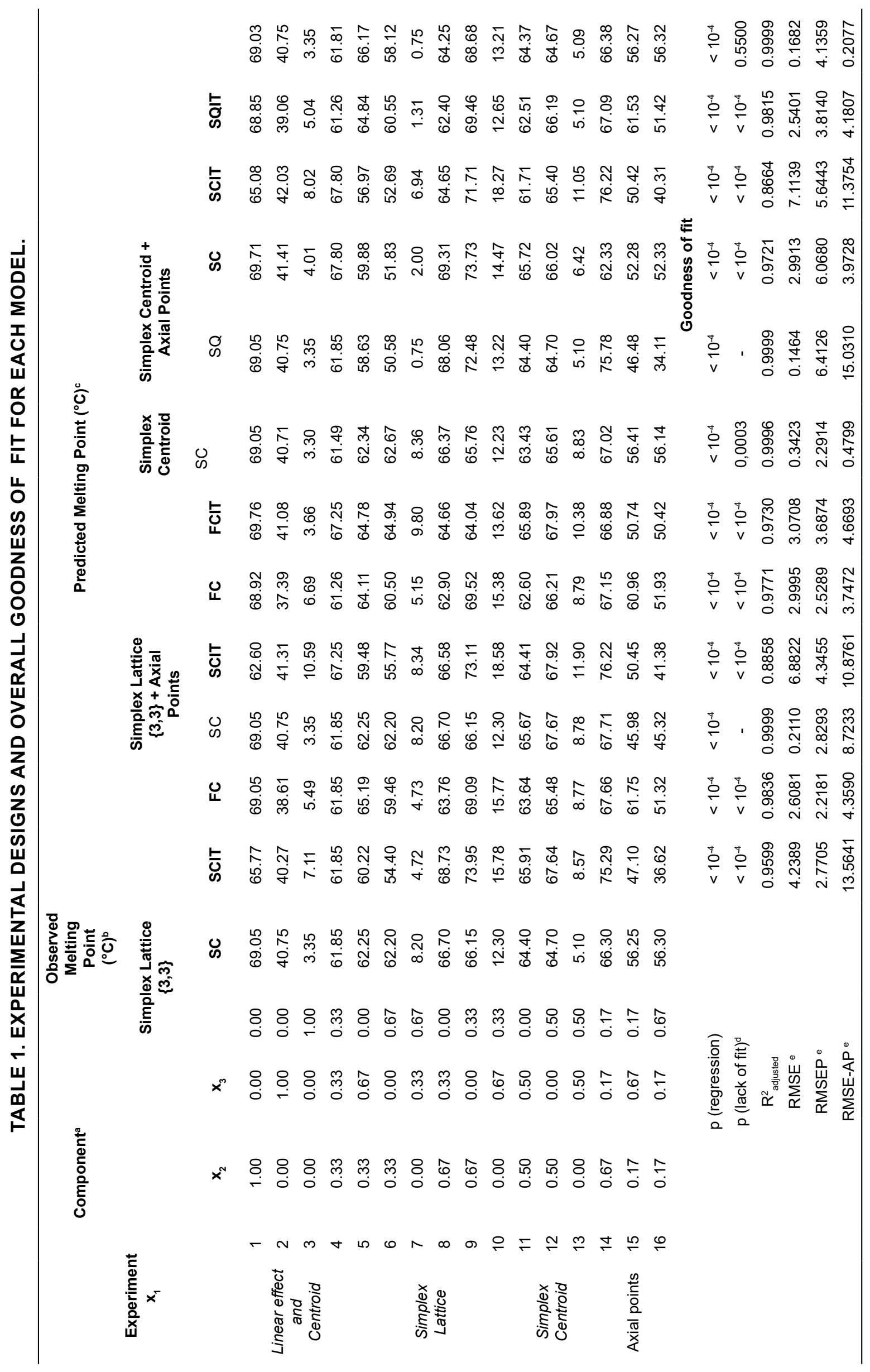


${ }^{\mathrm{a}} \mathrm{x}_{1}=$ stearic acid; $\mathrm{x}_{2}=$ lard; $\mathrm{x}_{3}=$ peanut oil. $/{ }^{\mathrm{b}}$ Average of two experiments. $/{ }^{c}$ Models: $\mathrm{SC}=\mathrm{Special}$ Cubic; $\mathrm{SCTI}=\mathrm{Special}$ Cubic with Inverse Term; FC = Full Cubic; FCIT = Full Cubic with Inverse Term; SQ = Special Quartic; SQIT = Special Quartic with Inverse Term. d $^{\mathrm{A}}$ For some models there is no degree of freedom to make the lack of fit test./ ${ }^{\mathrm{e}} \mathrm{RMSE}$ : root mean square error for regression samples; RMSE: root mean square error for prediction samples; RMSE-AP : root mean square error for axial points.

RMSE $=\sqrt{\frac{1}{N} \sum_{i=1}^{N}(y-\hat{y})^{2}}$

In Equation (5), is the root mean square error, is the number of experiments used for error calculation, is the melting point experimentally observed and is the predicted value for the melting point.

First, a multivariate regression analysis is necessary to estimate a good model. In this analysis the unknown parameters of the regression model are estimated and the adequacy of the model as well as the quality of the obtained adjustment is verified. If this verification indicates that the model is not appropriate, it should be modified and its parameters must be re-estimated (MONTGOMERY, 2005) in an iterative procedure. Models parameters estimation was made by the least-squares method and the quality of fit was evaluated by ANOVA.

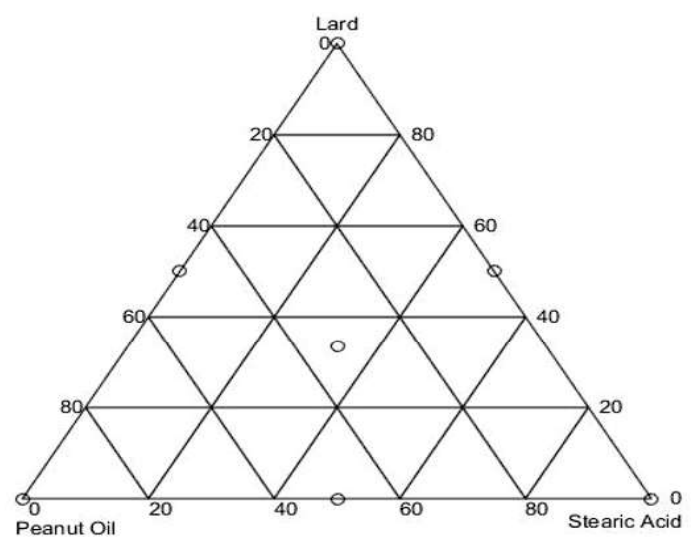

(a) Simplex Centroid

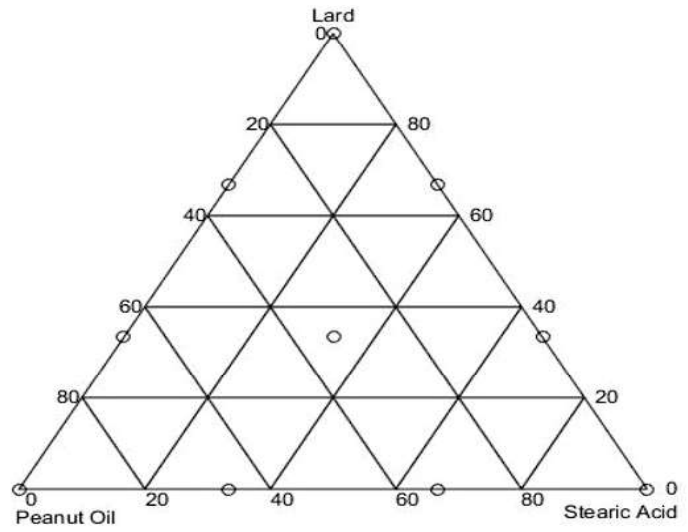

(c) $\{3,3\}$ Simplex Lattice

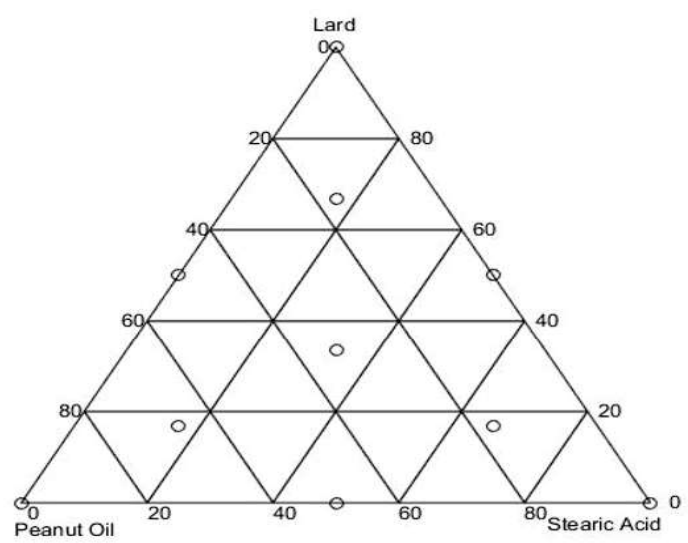

(b) Simplex Centroid with axial points

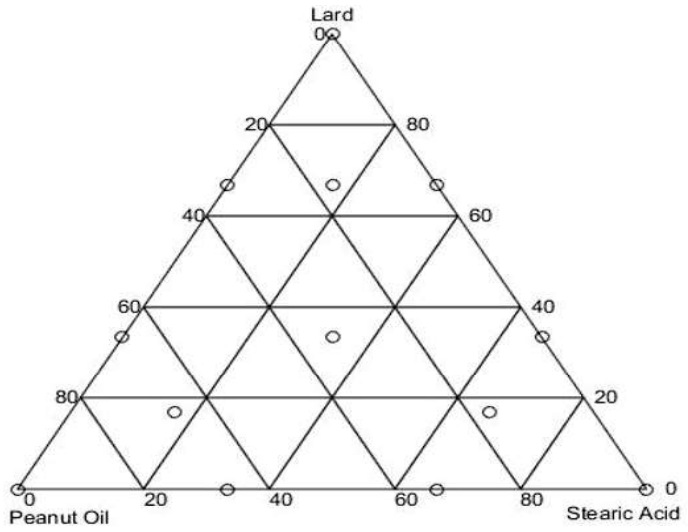

(d) $\{3,3\}$ Simplex Lattice with axial points

\section{FIGURE 1. MIXTURE DESIGNS THAT WERE COMPARED FOR THE PREDICTION OF THE TERNARY LIPID MIXTURE MELTING POINT. THE POINTS INDICATE THE COMPOSITION OF THE EVALUATED MIXTURES.}

\subsection{LIPID MIXTURES PREPARATION AND MELTING POINT DETERMINATION}

The lipid mixtures were prepared with a total weight of $1 \mathrm{~g}$, keeping the proportions between mixtures components indicated by each experimental design (Figure 1 and Table 1). Lard, peanut oil and stearic acid were weighted in a beker and melted under gentle stirring in a heating plate. Then, the mixtures were imediatly frozen $\left(-18^{\circ} \mathrm{C}\right)$ to solidify. 
The determinations of melting point for mixtures and pure components were carried out according to CC1-25 method from American Oil Chemists' Society (1990). For that a capillary tube was dipped into the solid lipid mixture, initially at $-18^{\circ} \mathrm{C}$, to be filled to about $10 \mathrm{~mm}$ high in the tube. After that both ends of the tube were fused with a flame. Then, the capillary tube containing the lipid mixture was attached to a mercury thermometer and both were suspended inside a borosilicate jacketed vessel $(100 \mathrm{~mL})$, that was previously filled with distilled water and connected to a thermostatic bath (Quimis, Q214M) with temperature set at $0{ }^{\circ} \mathrm{C}$. The thermostatic bath temperature was then raised at $1^{\circ} \mathrm{C} \cdot \mathrm{min}^{-1}$ and the melting point was determined visually when the mixture inside the tube was completely clear. All experimental determinations were obtained in triplicate.

\section{RESULTS AND DISCUSSION}

Results related to melting points determinations, experimental designs and overall goodness of fit for each model are presented at Table 1. The quadratic model (Equation (4)) presented the worst performance compared to higher-order models for all tested designs, thus, the results for these models were omitted in Table 1.

All models showed high adjusted determination coefficients $\left(R^{2}{ }_{\text {adjusted }}\right)$ and were statistically significant with very low probabilities of type I error $\left(p<10^{-4}\right)$. However, RMSE results presented a quite varied behavior with errors in the range from 0.15 to $15.0310{ }^{\circ} \mathrm{C}$. In the case of simplexlattice design the inclusion of axial points leaded to a reduction in the error with respect to these points (RMSE-AP). However, for both, SC and FC models, when RMSE, RMSEP and $\mathrm{R}^{2}$ adjusted are evaluated, a worse predictive ability of the models can be observed. A similar behavior was observed for the SC model. On the other hand, the addition of the axial points in the simplexcentroid design allowed the construction of the special quartic model that resulted in an improved predictive ability.

However, for all designs presented in Table 1 that have been mentioned so far, a statistically significant lack of fit was found. This fact shows that experimental deviations as well as pure error did not have homoscedasticity of variance compromising the reliability of model predictions. According to Mertens and Deman (1972), natural fats do not melt in a strict temperature but present a melting range, which can result in variations in its determination and generate poor reproducibility. Moreover, unlike pure compounds, natural vegetable oils have no true melting points because they are composed by a complex mixture of triglycerides which passes through a gradual softening before becoming completely liquid (FASINA et al., 2008). Severino et al. (2011) analyzing stearic acid by differential scanning calorimetry found onset and endset melting temperatures of $70.1^{\circ} \mathrm{C}$ and $81.1^{\circ} \mathrm{C}$, respectively. Maw et al. (2003) conducted a study to evaluate the effect of lard fatty acids composition on the color and hardness of the product. The fatty acid profile of white colored lard, same kind applied at the present work, was evaluated by Gas Chromatography and showed the following composition: $1.59 \%$ myristic acid (C14:0); 25.4\% palmitic acid (C16:0); 2.69\% palmitoleic acid (C16:1); 12.4\% stearic acid (C18:0); 42.4\% oleic acid (C18:1); $14.3 \%$ linoleic (C18:2); 1.19\% $\alpha$-Linolenic acid (C18:3). In the study of (SERRA et al., 2014) the composition of these fatty acids was detected in Colonnata" lard from Large White pigs as follows: : 1.38\% myristic acid (C14:0); $21.16 \%$ palmitic acid (C16:0); 1.41\% palmitoleic acid (C16:1); 13.13\% stearic acid (C18:0); $31.83 \%$ oleic acid (C18:1); $8.37 \%$ linoleic (C18:2); $0.45 \%$ a-Linolenic acid (C18:3). Furthermore, according to (FASINA et al., 2008) peanut oil presents a large melting range, having onset melting temperature $(-20.05$ $\left.{ }^{\circ} \mathrm{C}\right)$, a maximum peak at $-0.73^{\circ} \mathrm{C}$ and melting temperature endset at $-10.37^{\circ} \mathrm{C}$. The lack of adjustment presented may be related to this fact. Pelissari and others (2012) showed lack of fit for a mixture model for cassava starch films and chitosan and commented that this result was due to the small value obtained for the pure error and concluded that this result did not affected 
model's predictive ability. It is worth noting that pure error obtained here presented a similar behavior to that described by Pelissari and others (2012).

In Figure 2 the ternary diagrams obtained with the full cubic model for $\{3,3\}$ simplex-lattice design (Figure 2(a)) and for the special quartic model for simplex-centroid design (Figure 2(b)) are shown. By inspection of these diagrams a dramatic reduction in the melting point can be observed when the amount of stearic acid is close to zero. In these cases, it is recommended (CORNELL, 2011) the augmentation of the Scheffé polynomials with the additional inverse terms of the form $\beta_{-i}$ $x_{i}^{-1}$ included to account for the possible extreme change in the response as $x_{i}$ approaches zero. Thus, for all design models tested, if there was enough degrees of freedom, the term $\beta_{-1} x_{1}^{-1}$ was added. At Table 1 the models with inverse term were identified with the suffix IT. When compared to the respective models without inverse term, in all cases, the effect from the inverse term was statistically significant $(p<0.05)$ and there was an increase on models predictive ability. It also can be highlighted that the model FCIT presented a good predicting ability for both, binary mixtures and axial points, but it still presents a statistically significant lack of fit. On the other hand, the model SQIT did not presented a good prediction to binary mixtures, but for axial points there was a satisfactory prediction and there was no statistically significant lack of fit.
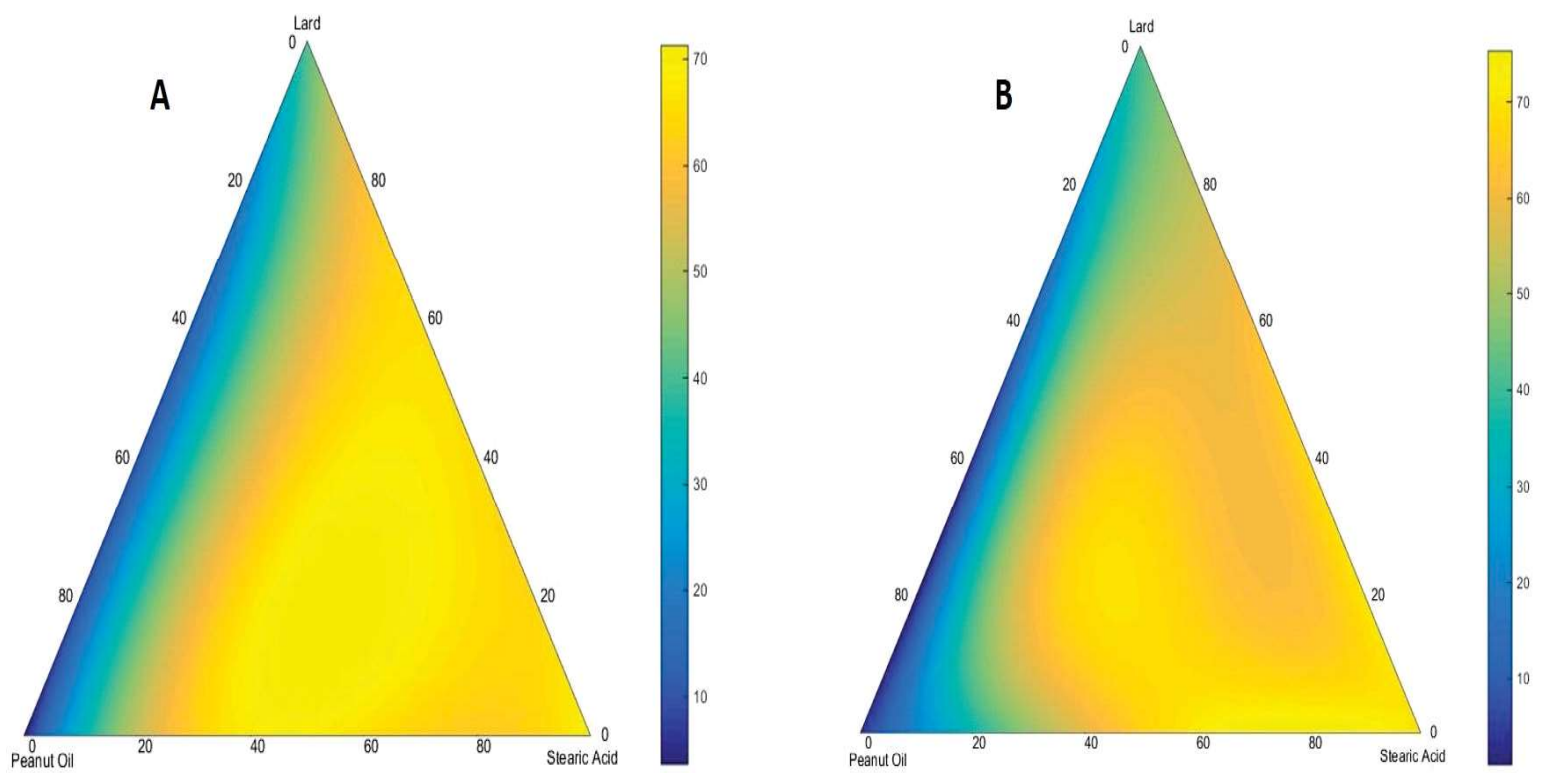

FIGURE 2. TERNARY DIAGRAMS: (A) \{3,3\} SIMPLEX-LATTICE WITH AXIAL POINTS AND FULL CUBIC MODEL; (B) SIMPLEX-CENTROID WITH AXIAL POINTS AND SPECIAL QUARTIC MODEL.

In Table 2 the coefficients and the respective standard errors for FCIT e SQIT models are presented. Linear effects presented quite similar values, being this behavior related to the melting point of the individual components (stearic acid $>$ lard $>$ peanut oil). The quadratic effects also presented similar values for both models indicating a synergic interaction between stearic acid and peanut oil as well as an antagonist interaction between lard and the other two mixture components. According to Maw et al. (2003) fatty acid from lard presents a great variability in function of nutrition, sex, breed, and rearing temperature. Authors evaluated lard composition from pigs from different origins and observed that the major components are mainly myristic, palmitic, stearic, oleic, linoleic and a-linolenic acids. Peanut oil also present variations in composition (WORTHINGTON; HAMMONS; ALLISON, 1972). Probably the interaction between stearic acid and lard compounds, as well as between components from peanut oil and lard promotes such antagonist effect on melting temperature of the mixture.

All cubic terms $\delta_{i j}$ were significant to FCIT model, enabling one to detect both synergistic and antagonistic blending between the components $i$ and $j$ (CORNELL, 2011). Furthermore, the cubic interaction $\beta_{123}$ was significant indicating a synergism for the ternary mixture. At SQIT model, 
quadratic terms $\gamma_{1223}$ and $\gamma_{1233}$ were significant and they are especially useful for detecting a type of asymmetry of the surface in the interior of the triangle that cannot be picked up by cubic terms $\delta_{i j}$ (CORNELL, 1986). According to Cornell (2011), simplex-lattice designs produce good models for binary mixtures prediction, while simplex-centroid designs produce good models to ternary mixtures prediction.

TABLE 2. COEFFICIENTS AND STANDARD ERRORS FOR THE BEST MODELS FOR SIMPLEX-LATTICE AND SIMPLEX-CENTROID WITH AXIAL POINTS DESIGNS.

\begin{tabular}{|c|c|c|c|c|}
\hline \multirow[b]{2}{*}{ Effect } & \multicolumn{2}{|c|}{ Full Cubic with Inverse Term ${ }^{a}$} & \multicolumn{2}{|c|}{ Special Quartic with Inverse Term ${ }^{b}$} \\
\hline & Coefficient & Standard Error & Coefficient & Standard Error \\
\hline$\beta_{1}$ & 69.05 & 0.19 & 69.03 & 0.16 \\
\hline$\beta_{2}$ & 74.53 & 0.60 & 74.77 & 0.36 \\
\hline$\beta_{3}$ & 37.10 & 0.60 & 37.37 & 0.36 \\
\hline$\beta_{12}$ & -33.44 & 1.52 & -30.11 & 0.98 \\
\hline$\beta_{13}$ & 50.12 & 1.52 & 45.89 & 0.98 \\
\hline$\beta_{23}$ & -52.70 & 0.83 & -67.84 & 0.78 \\
\hline$\beta_{123}$ & 142.17 & 7.24 & - & - \\
\hline$\delta_{12}$ & 39.50 & 2.38 & - & - \\
\hline$\delta_{13}$ & -51.01 & 2.38 & - & - \\
\hline$\delta_{23}$ & -58.10 & 1.59 & - & - \\
\hline$\gamma_{1123}$ & - & - & $-17.51^{\circ}$ & 28.31 \\
\hline$\gamma_{1223}$ & - & - & -378.75 & 16.84 \\
\hline$\gamma_{1233}$ & - & - & 962.17 & 16.84 \\
\hline$\beta_{-1}$ & $-3.38 \times 10^{-4}$ & $5.73 \times 10^{-6}$ & $-3.40 \times 10^{-4}$ & $3.43 \times 10^{-6}$ \\
\hline
\end{tabular}

a Equation (2) with inverse term for stearic acid.

${ }^{b}$ Equation (3) with inverse term for stearic acid.

${ }^{\mathrm{c}}$ Is not statistically significant $(p>0.05)$.

In Figure 3 the response surface obtained for FCIT e SQIT are presented. It is worth noting that models were able to predict the melting temperature of the lipid mixtures from 3 to $69^{\circ} \mathrm{C}$ and the exact composition to be used will depend on the desired critical temperature. As an example, one may need to use a composition to formulate a critical temperature indicators for chilled foodstuff with $10^{\circ} \mathrm{C}$ as the target temperature since, according to Silva (2014), when reaching this temperature such products may show deterioration of sensory properties and development of pathogenic microorganisms. According to Figure 3, for both models the mixtures that have melting profile around $10^{\circ} \mathrm{C}$ are those which have higher proportions of peanut oil and lard instead of stearic acid. It can also be observed that the use of small amounts of stearic acid, considerably raise the melting point of the mixtures. 

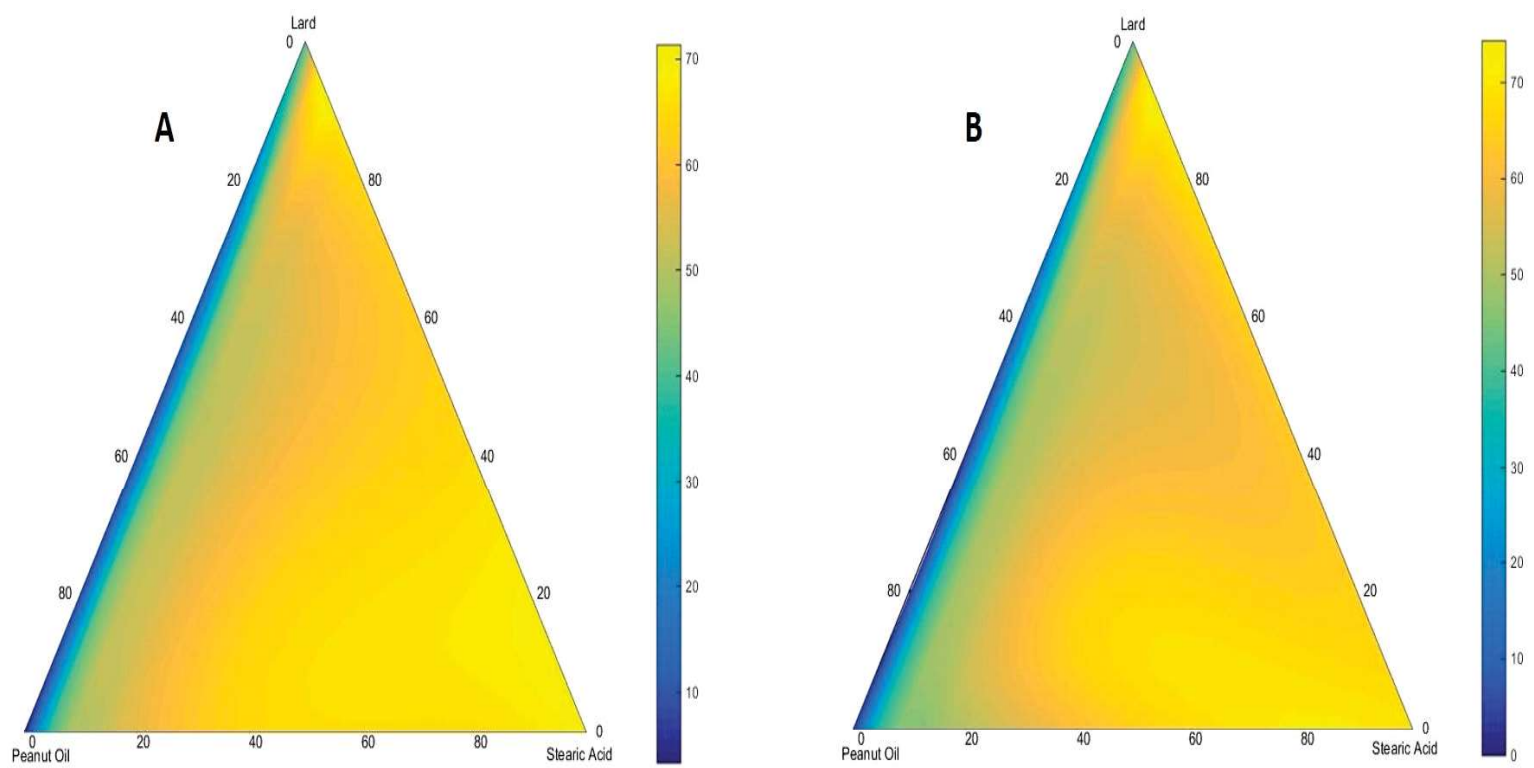

FIGURE 3. TERNARY DIAGRAMS: (A) \{3,3\} SIMPLEX-LATTICE WITH AXIAL POINTS AND FULL CUBIC WITH INVERSE TERM MODEL; (B) SIMPLEX-CENTROID WITH AXIAL POINTS AND SPECIAL QUARTIC WITH INVERSE TERM MODEL.

\section{CONCLUSIONS}

Mixture experimental design approach was applied in order to evaluate the melting point of a system composed by stearic acid, lard and peanut oil aiming a future application as critical temperature indicator. Simplex-lattice and simplex-centroid designs were able to describe the behavior of the melting temperatures in a wide range. Notably, the inclusion of axial points and the inverse term greatly increased the predictive ability of the models. Simplex-lattice design demonstrated improved ability to predict melting point of binary mixtures while the simplexcentroid design yielded an improved model for predicting melting temperatures of the ternary mixtures.

\section{RESUMO}

\section{MODELAGEM DA TEMPERATURA DE FUSÃO DE UM INDICADOR DE TEMPERATURA CRIITICA À BASE DE LIPÍDIO: UMA COMPARAÇÃO ENTRE DESIGN DE SIMPLEX- LATTICE E SIMPLEX-CENTROID}

Indicadores de Temperatura Crítica (ITC) são aplicados na industria de alimentos em casos em que o alimento não deve ser descongelado ou em que uma temperatura específica não seja alcançada, indicando alterações por meio visual como fusão, modificação de cor, etc. Misturas de lipídeos são candidatos a produção de ITC já que a temperature final de fusão da mistura pode se manipulada pela proporção de cada lipídeo. Neste trabalho uma mostura de lipídeos constistindo de ácido esteárico, banha de porco e óleo de amendoim foi usada para desenvolver um ITC. Os planejamentos experimentais Simplex-lattice e Simplex-centroid foram comparados para modelar a temperatura de fusão da mistura, obtida pelo método de do tubo capilar (CC1-25, AOCS). A adição de pontos axiais aos modelos experimentais melhourou a capacidade preditiva dos modelos enquanto que a inclusão de termos inversos foi necessária para aumentar a acurácia dos modelos. O modelo simplex-lattice apresentou a melhor habilidade de predição do ponto de fusão de misturas binárias 
dos componentes, enquanto que o modelo simplex-centroid resultou em uma melhor predição do ponto de fusão de misturas ternárias.

PALAVRAS-CHAVE: SIMPLEX-LATTICE; SIMPLEX-CENTROID; ÁCIDOS GRAXOS; PONTO DE FUSÃO.

\section{REFERENCES}

1 BIJI, K. B. et al. Smart packaging systems for food applications: a review. Journal of Food Science and Technology, v. 52, n. 10 , p. $6125-6135,2015$.

2 BRITO, I. L. et al. Nutritional and sensory characteristics of gluten-free quinoa (Chenopodium quinoa Willd)-based cookies development using an experimental mixture design. Journal of Food Science and Technology, v. 52, n. 9, p. 5866-5873, 2014.

3 CORNELL, J. A. A comparison between two ten-point designs for studying three-component mixture systems. Journal of Quality Technology, v. 18, n. 1, p. 1-15, 1986.

4 CORNELL, J. A. A Primer on Experiments with Mixtures. 1. ed. Hoboken: John Wiley \& Sons, 2011.

5 DOGAN, M. et al. Optimization of gum combination for instant pudding based on creep and recovery parameters by mixture design approach. European Food Research and Technology, v. 238, n. 1, p. 47-58, 2014.

6 FASINA, O. O. et al. Predicting melting characteristics of vegetable oils from fatty acid composition. LWT - Food Science and Technology, v. 41, n. 8, p. 1501-1505, 2008.

7 KOUAKOU, A. C.; LE MAPIHAN, K.; PAULY, J. Solid-liquid equilibria under high pressure of pure fatty acid methyl esters. Fuel, v. 109, p. 297-302, 2013.

8 LIMPISOPHON, K.; TANAKA, M.; OSAKO, K. Characterisation of gelatin-fatty acid emulsion films based on blue shark (Prionace glauca) skin gelatin. Food Chemistry, v. 122, n. 4, p. 1095-1101, out. 2010.

9 LIU, K. J.; CHANG, H. M.; LIU, K. M. Enzymatic synthesis of cocoa butter analog through interesterification of lard and tristearin in supercritical carbon dioxide by lipase. Food Chemistry, v. 100, n. 4, p. 1303-1311, 2007.

10 MAW, S. J. et al. Physical characteristics of pig fat and their relation to fatty acid composition. Meat Science, v. 63, n. 2, p. 185-190, 2003.

11 MERTENS, W. G.; DEMAN, J. M. Automatic Melting Point Determination of Fats. Journal of the American Oil Chemists Society, v. 49, p. 366-370, 1972.

12 MONTGOMERY, D. C. Design and Analysis of Experiments. 6. ed. Hoboken: John Wiley \& Sons, 2005.

13 MÜLLER, R. H.; RADTKE, M.; WISSING, S. A. Solid lipid nanoparticles (SLN) and nanostructured lipid carriers (NLC) in cosmetic and dermatological preparations. Advanced drug delivery reviews, v. 54, n. 1, p. 131-155, 2002.

14 MYAT, M. W. et al. Physicochemical and sensory characteristics of palm olein and peanut oil blends. Journal of Food, Agriculture and Environment, v. 7, n. 3-4, p. 175-181, 2009.

15 NETO, B. D. B.; BRUNS, R. E.; SCARMINO, I. S. Como Fazer Experimentos: Pesquisa e desenvolvimento na ciência e na indústria. 4. ed. Porto Alegre: Bookman, 2010.

16 NIKZADE, V.; TEHRANI, M. M.; SAADATMAND-TARZJAN, M. Optimization of low-cholesterol-low-fat mayonnaise formulation: Effect of using soy milk and some stabilizer by a mixture design approach. Food Hydrocolloids, v. 28, n. 2, p. 344-352, 2012.

17 PACHECO, C. et al. Optimization of reaction conditions in the enzymatic interesterification of soybean oil and fully hydrogenated soybean oil to produce plastic fats. JAOCS, Journal of the American Oil Chemists' Society, v. 90, n. 3, p. 391-400, 2013.

18 PAVELKOVÁ, A. Time temperature indicators as devices intelligent packaging. Acta Universitatis Agriculturae et Silviculturae Mendelianae Brunensis, v. 61, n. 1, p. 245-251, 2013.

19 PELISSARI, F. M. et al. Constrained mixture design applied to the development of cassava starch-chitosan blown films. Journal of Food Engineering, v. 108, n. 2, p. 262-267, 2012.

20 PEREIRA, V. D. F. et al. Avaliação de temperaturas em câmaras frigoríficas de transporte urbano de alimentos resfriados e congelados. Ciência e Tecnologia de Alimentos, v. 30, n. 1, p. 158-165, 2010.

21 SENGAR, G.; SHARMA, H. K.; KUMAR, N. Effect of Microwave heating on physico-chemical and thermal behavior of blended fat. International Food Research Journal, v. 22, n. 1, p. 295-303, 2015. 
22 SERRA, A. et al. Fatty acid composition, oxidation status and volatile organic compounds in "Colonnata" lard from Large White or Cinta Senese pigs as affected by curing time. Meat Science, v. 97, n. 4, p. 504-512, 2014.

23 SETIOWATY, G.; MAN, Y. B. C. Determination of slip melting point in palm oil blends by partial least squares and principal component regression modeling of FTIR spectroscopic data. Journal of the American Oil Chemists' Society, v. 79, n. 11, p. 1081-1084, 2002.

24 SEVERINO, P. et al. Polymorphism, crystallinity and hydrophilic-lipophilic balance of stearic acid and stearic acid-capric/ caprylic triglyceride matrices for production of stable nanoparticles. Colloids and Surfaces B: Biointerfaces, v. 86, n. 1, p. 125-130, 2011.

25 SHIMONI, E.; ANDERSON, E. M.; LABUZA, T. P. Reliability of Time Temperature Indicators Under Temperature Abuse. JOURNAL OF FOOD SCIENCE, v. 66, n. 9, p. 1337-1340, 2001.

26 SILVA, J. . L. Microbiologia. Disponível em: <http://www.agencia.cnptia.embrapa.br/gestor/tecnologia_de_alimentos/ arvore/CONT000fid3s5b702wyiv80z4s473eq236p2.html>>. Acesso em: 3 out. 2014.

27 SILVA, R. C. DA; GIOIELLI, L. A. Propriedades físicas de lipídios estruturados obtidos a partir de banha e óleo de soja. Revista Brasileira de Ciências Farmacêuticas, v. 42, n. 2, 2006.

28 SMOLANDER, M. et al. Monitoring of the quality of modified atmosphere packaged broiler chicken cuts stored in different temperature conditions. A. Time-temperature indicators as quality-indicating tools. Food Control, v. 15, n. 3, p. 217-229, 2004.

29 TAOUKIS, P. S. Modelling the use of time-temperature indicators in distribution and stock rotation. In: TIJSKENS, L. M. M.; HERTOG, M. L. A. T. M.; NICOLAÏ, B. M. (Eds.). . Food process modeling. 1st. ed. Washington, DC, USA: CRC Press, 2001. p. 402-432.

30 WANG, S. et al. Review of Time Temperature Indicators as Quality Monitors in Food Packaging. Packaging Technology and Science, v. 28, n. 10, p. 839-867, 2015.

31 WORTHINGTON, R. E.; HAMMONS, R. 0.; ALLISON, J. R. Varietal Differences and Seasonal Effects on Fatty Acid Composition and Stability of Oil from 82 Peanut Genotypes. Journal of Agricultural and Food Chemistry, v. 20, n. 3, p. 727-730, 1972.

32 YANG, T. et al. Lipase-catalyzed modification of lard to produce human milk fat substitutes. Food Chemistry, v. 80, n. 4, p. 473-481, 2003.

33 YIN, Y.-C. et al. Surface modification of sodium caseinate films by zein coatings. Food Hydrocolloids, v. 36, p. 1-8, maio 2014.

34 ZABALA, S.; CASTÁN, J.; MARTÍNEZ, C. Development of a time-temperature indicator (TTI) label by rotary printing technologies. Food Control, v. 50, p. 57-64, 2015. 